\title{
SOLIDARISME OU BARBARIE: WELFARE AND THE 'SOCIAL QUESTION’ IN FRANCE
}

Ed Naylor

Franz-Xaver Kaufmann, Variations of the Welfare State: Great Britain, Sweden, France and

Germany between Capitalism and Socialism (Berlin: Springer-Verlag, 2013), 250 pp. (hb), £72, ISBN 978-3-642-22548-2.

Benoît Charenton, Léopold Bellan, un pionnier de l'humanitaire (Paris: Le Cherche Midi, 2008), 237 pp. (hb), €24.35, ISBN 978-2-7491-1251-0.

Eric Jabbari, Pierre Laroque and the Welfare State in Post-war France (Oxford: Oxford University Press, 2012), 188 pp. (hb), £69, ISBN 978-0-19-928963-9.

Jean-Pierre Le Crom, Au Secours Maréchal! L'instrumentalisation de l'humanitaire (1940-44)

(Paris: Presses universitaires de France, 2013), 344 pp. (pb), €22, ISBN 978-2-13-061938-3.

The 2014 Avignon Festival opened under the threat of strike action. Actors and technicians belonging to the trade union branch CGT Spectacle were protesting against changes to the social security regime for intermittents (literally, intermittent workers), and several plays were cancelled during the first week of July. When asked to comment, festival director Olivier Py told journalists: 'To strike is a right, not to strike is a right, and Avignon is a democracy', but added, 'Personally, I 
think that not performing is not the right solution'. ${ }^{1}$ He also stated that he was 'obviously in solidarity with a movement that calls on the government to take more account of job insecurity' (précarité). These attempts to be diplomatic did not satisfy everyone, and a section of the protesters heckled him with shouts of 'Olivier qui?' This must have been rather galling for the renowned theatre director, who, as cabaret alter-ego 'Miss Knife', once memorably sang: 'When the bourgeoisie demands a little excess, I'm the glob of puss that squirts from its abscess'.2

The intermittent regime is a sort of fast-tracked unemployment insurance adapted to the volatile nature of work in the performing arts sector, allowing artists and technicians to accumulate a succession of fixed-term contracts of short duration. ${ }^{3}$ To qualify, individuals must reach a certain threshold of hours worked in the course of a year which then entitles them to receive unemployment payments between contracts and thereby maintain a relatively stable income.

Like French social insurance as a whole, the intermittent regime is a contributions-based system; what you receive is closely linked to what you pay in. Thus, while an actor working in provincial theatre usually struggles to clear much more than $€ 1000$ per month (the average annual income of intermittents is $€ 13,700$ ), a minority of the estimated 100,000 who actually draw these

1 The author would like to warmly thank Jessica Wardhaugh and Julian Jackson for their comments and assistance with the preparation of this article. CEISR, Faculty of Humanities and Social Sciences, University of Portsmouth, Park Building, King Henry I Street, Portsmouth, PO1 2DZ. ed.naylor@port.ac.uk

'Festival d'Avignon: "Ne pas jouer n'est pas la bonne solution”, selon Olivier Py', Le Monde, 12 July 2014.

2 'Quand la bourgeoisie réclame un peu d'excès, je suis la goutte de pus qui sort de son abcès', Olivier Py, Les ballades de Miss Knife, Actes Sud, 2002.

3 This had originated in the 1930s as a regime for those employed on film shoots. 
benefits can earn incomes more than four times greater without forfeiting intermittent status. This episode formed just a small part of wider government-brokered negotiations over reform involving the 'social partners' - trade union and business representatives - but it serves to illustrate three key features of the contemporary welfare state in France. ${ }^{4}$

First is the widely noted attachment of the French public to the system, notwithstanding its institutional complexity. Although the status of intermittent derives from a technical regime of social insurance contributions, this has not prevented it from becoming a professional status label to which many young performing artists aspire. ${ }^{5}$ Second, France's contributions-based system does not redistribute wealth significantly between income groups. Instead, redistribution is primarily between generations (in that current workers fund the pensions of the retired) and between childraising and non-child-raising households (through family allowances). ${ }^{6}$ Third is the long-standing importance of the term 'solidarity' as a guiding principle and value said to be embodied in the French social model. Py used the word in a broad political sense (in solidarity with a cause that he hoped would not disrupt his festival) but when applied to the nitty-gritty of taxation and wealth redistribution it is no less ambivalent.

4 Central to the current negotiations is a proposed 'pact for employment' whereby social security charges for employers can be reduced in return for the latter's participation in job-creating initiatives.

5 Even at the sharp end of the labour market, acronyms have been adopted and internalised as not-always-flattering labels, such as RMIste (the RMI is an unemployment benefit tied to compulsory training) and SMICard (referring to the minimum wage rate).

6 Susan Milner, 'Social Policy and France’s “Exceptional” Social Model', in Tony Chafer and Emmanuel Godin, eds., The End of The French Exception? Decline and Revival of the 'French Model' (Palgrave Macmillan: Basingstoke, 2010), 56. 
The four books under review here are very different in their themes and methodological approaches, but each offers insights into the origins of the welfare system in contemporary France. Only two of the works deal directly with its institutional development, the other two addressing Belle Epoque philanthropy and humanitarian aid under Vichy respectively. One shared thread, however, is the malleable concept of solidarity, a recurring trope in aspirations to promote social cohesion and chart a 'third way' between liberal individualism and socialist collectivism.

The first of these books, Variations of the Welfare State, places the French social model within a wider comparative framework. Written by political scientist Franz-Xaver Kaufmann and translated into English, it examines the development of welfare states in Germany, Sweden, France and Britain and aims to highlight national 'idiosyncrasies'. The author begins by situating his study within a predominantly social scientific literature, and the result is more history in the service of political science than the reverse. Kaufmann proceeds from the assumption that welfare state regimes (or 'welfare production', as he terms it) should not be classified simply in terms of their institutional configurations or by the measurement of their (redistributive) outcomes (Kaufmann, 39). Instead, he argues that what characterises them is a democratic political consensus that legitimises collective intervention on behalf of each individual member of a society. On this basis he excludes both the former USSR (a 'socialist' state) and the United States (a 'capitalist' state), before turning to examine the four countries that constitute his sample.

The goal Kaufmann sets himself is to clarify the 'inner logic' and shape (Gestält) of the welfare sector in each country by examining its historical development. Within a set of defined parameters the aim is to 'seek out guiding articulations of problems that have exerted a longer-term influence, in a country's welfare state development, on both discourses as well as the institutional development (sic)' (Kaufmann, 32). In this way he considers in turn the relationship between state and society (or the public and private realms), how the 'social question' was articulated and then the 
structures that have emerged in each of three principal domains: production (industrial relations and employment law), distribution (taxation and benefits) and reproduction (education and personal services). In a work of little more than 200 pages this is an ambitious agenda, and Kaufmann warns the reader that his sketches required 'simplifications, indeed, gross simplifications' (Kaufmann, 44). Based for the most part on German-language secondary literature that pre-dates the mid-1990s, the country outlines are indeed likely to be familiar to specialist readers. The survey of France is patchy and at times prone to caricature, like the observation that 'to this day one can hardly speak of local self-government, all the efforts at décentralisation notwithstanding' (Kaufmann, 145), or to dubious generalisations, such as 'France has remained, more strongly than all the countries under comparison, a society of obvious social inequalities' (Kaufmann, 168). Alongside Sweden and Germany this is most probably the case, but it seems less plausible when Britain is taken into account. $^{7}$

Notwithstanding these shortcomings, Kaufmann's approach is thought-provoking and offers useful insights. Esping-Andersen's classic typology identified three forms of welfare state: conservative/continental (Germany and France), social democratic (Sweden) and liberal (the UK). ${ }^{8}$ His influential classification was largely based upon 'decommodification': the extent to which a system insulates living standards from market forces. However, this analysis rested on income

7 Looking at one concrete measure, the OECD Gini index since 1999, France and Germany are rather close, with the former rising slowly from 0.28 to reach 0.3 in 2010 , and the latter hovering between 0.26 and 0.28 . Sweden records the lowest inequalities (between 0.23 and 0.27), while Britain has the highest (oscillating between 0.33 and 0.35 ). Confusingly, Kaufmann himself refers to (older) OECD data on the Gini coefficient in his conclusion, which seems to mark Britain as the group outlier on inequalities (Kaufmann, 217).

8 Gosta Esping-Andersen, The Three Worlds of Welfare Capitalism (Princeton: Princeton University Press, 1990). 
redistribution and therefore missed other mechanisms that Kaufmann integrates into his comparisons; for example, while the British system is fairly miserly on transfers (state pensions), it partially compensates through services (the NHS).

Particularly relevant to this article is Kaufmann's discussion of the role played by various formulations of the 'social question' in the historical development of welfare regimes. A ubiquitous concept in late nineteenth and early twentieth century public debate, as Kaufmann notes it was frequently employed as a shorthand for tensions resulting from industrialisation and rapid urbanisation by those seeking to mediate them within the framework of a capitalist order. In this sense the emergence of welfare states 'related to problems of social integration and coherence' (Kaufmann, 31), and the author combines functionalist and conflict-theoretical explanations of this development in a way that leaves space to reflect on national specificities. ${ }^{9}$ In other words, different questions led to different responses: for Germany, on which the typology is clearly based, it was the 'workers question', for Sweden the preservation of an egalitarian tradition, for Britain the problem of poverty, and for France that of demography.

Drawing on the work of Sue Pedersen, Kaufmann provides an effective discussion of how low birth rates through the nineteenth century gave rise to a French pro-natalist consensus which, combined with a weak and divided trade union movement, favoured the emergence of employercontrolled family allowances in contrast to the 'male bread-winner' model of Germany and

9 An influential example of the latter approach is Peter Baldwin, The Politics of Social Solidarity: Class Bases of the European Welfare State 1875-1975 (Cambridge: Cambridge University Press, 1990). 
Britain. ${ }^{10}$ Though the original impetus withered away under the Fifth Republic, its legacy remains to this day in a system that is particularly effective at tackling child poverty (Kaufmann, 155).

In seeking to highlight the 'autonomous cosmologies' (Kaufmann, 33) underpinning welfare states Kaufmann builds an interesting comparative framework that privileges differences as much as similarities. Historical synthesis on this scale requires some broad brush-strokes, but the result is a plausible account of welfare state regimes and their diverse configurations.

In contrast, Benoît Charenton examines the 'social question' on a very different scale, through a study of the life and works of Parisian philanthropist Léopold Bellan (1857-1936) during the Third Republic. An abridged version of a doctoral thesis defended in 2003, this copiously illustrated book contains a foreword by the current director of the foundation that still bears Bellan's name. ${ }^{11}$ From modest social origins Léopold Bellan established himself as a fairly successful entrepreneur in the textile district of Sentier in Paris's second arrondissement, but it was in his role of "“notable" de la philanthropie' (Charenton, 188) that he built a lasting legacy. Bellan

10 Sue Pedersen Family, Dependence, and the Origins of the Welfare State: Britain and France, 1914-45 (Cambridge: Cambridge University Press, 1993). There is now a substantial literature examining the history of French welfare through the lens of gender. See, for example, Laura Levine Frader, Breadwinners and Citizens: Gender in the Making of the French Social Model (London: Duke University Press, 2008); Christine Adams, Poverty, Charity, and Motherhood: Maternal Societies in Nineteenth-Century France (Chicago: University of Illinois Press, 2010); Kristen Stromberg Childers, Fathers, Families, and the State in France, 1914-45 (Ithaca and London: Cornell University Press, 2003).

11 Charenton's doctoral thesis was entitled 'Un Philanthrope sous la troisième République: la vie et l'œuvre de Léopold Bellan (1857-1936)', l'École nationale des chartes (2003). [place and year?] 
was a rather singular figure, yet, as Charenton shows, one whose philanthropic career was inseparable from the tightly knit Republican milieu in which he operated.

The Third Republic prior to the First World War has generally been noted for the relative timidity of its efforts in the area of social welfare provision. In contrast to Bismarck's social insurance schemes of the 1880s, the influence of laissez-faire liberal doctrine in France privileged notions of foresight (prévoyance) and self-help. From 1898 accident compensation legislation offered some protection to industrial workers, but the Charte de la Mutualité of the same year entrenched the role of mutual aid societies, while legislation on pensions did not emerge until 1910 and was far from universal or compulsory. Concerns about both urban and rural poverty - and about its implications for social cohesion - were, nonetheless, very much present among liberal Republicans as they sought to consolidate the democratic constitutional order. Reluctance to countenance state intervention on behalf of those able to work, or to interfere in relations between employer and employee, often saw reformist efforts centre on the destitute and vulnerable.

Central to the fledging social protection system that emerged in this period was '( $t$ )he Republic's willingness to cede to civic initiatives, indeed, its deep-seated preference for such initiatives.' $^{12}$ The holes in this edifice continued to be filled by religious charities but also by delegation to mutual aid societies, employer-sponsored arrangements and secular philanthropy. And it is here that Charenton situates Leopold Bellan's activities, emphasising 'the beginnings of a move from a logic of subsidiarity - where private initiatives filled the void of state action - to a logic of complementarity, where the state and private actors worked together to resolve the social question' (Charenton, 16). Echoing the importance of education in the liberal republican project, Bellan's first

12 Philip Nord, 'The Welfare State in France, 1870-1914', French Historical Studies, 18, 3 (1994), 837. 
ventures sought to bridge the gap between school and work through 'encadrement moral' ('pastoral tutelage') and vocational training. In 1894, he founded the Société d'enseignement moderne pour le développement de l'instruction d'adulte (The Modern Teaching Society for the Development of Adult Education, SEMDIA) that ran free evening classes taught by volunteers, generally young schoolteachers. By 1905 this was the largest such organisation in the Île-de-France, with some 20,000 students enrolled (Charenton, 41).

Bellan's initiatives clearly bore the influence of Belle Epoque solidarisme - indeed, SEMDIA's honorary president was the prominent Radical politician Léon Bourgeois, a leading exponent of the doctrine who published La solidarité in 1896. Attempting to navigate a course between liberalism and socialism, his philosophy was based upon a contractual understanding of human relations whereby the individual was in debt to society and thus had a moral duty to uphold solidarity between citizens and generations. Within a capitalist framework, this strain of solidarisme envisaged a degree of state intervention to help reconcile individual and collective goals, while favouring autonomous initiatives such as mutual aid societies and cooperatives. The nature and extent of public intervention and any redistributive implications remained vague - at a minimum those sympathetic to his ideas could cohere around a concern for equalising opportunities for individual advancement through education and 'giving back' through philanthropy. This seems to have been the case with Bellan, a moderate Republican who was firmly attached to the defence of private property and the commercial interests of his milieu (Charenton, 26).

Indeed, it was Bellan's network of connections - through business circles, freemasonry and municipal politics- that facilitated the breadth of his philanthropic work. Donations drawn from wealthy bourgeois patrons allowed him to establish two orphanages for girls by 1918, the year in which the SEMDIA became the Association Léopold Bellan. There followed a remarkable period of expansion and diversification, with the opening of further orphanages, boarding houses for young 
adults, housing for invalided war veterans, sanatoriums and preventoriums, and even a retirement home for former SEMDIA teachers. In a recurring pattern, each venture began with the purchase of a large property through bequests and donations, followed by recourse to public funds to provide for the long-term running costs. Many orphans moved through these institutions as they grew up, and by cultivating a family ethos the association sought to distinguish itself from the Assistance publique (state care) that was 'seen as cold and impersonal' (Charenton, 86-7).

Aimed at a general readership, Charenton's book offers a compelling portrait of republican philanthropy, one which is - generous rather than hagiographic - and is suggestive of how the somewhat nebulous ideals of solidarisme could translate into practice. Two unexamined questions linger in particular. First, for a man of avowedly secular and humanist convictions, the undertones of Christian piety in Bellan's pronouncements and the association's iconography make one wonder about the competition. The dynamism of social Catholicism in the wake of Pope Leo XIII's 1891 Rerum Novarum, as well as the 1905 separation of Church and state, are absent from this account. What common ground, if any, was there between religious charity and secular philanthropy at a local level, and what part did conflict or competition play? The second and more important omission is the perspective of the association's clientele. How did they respond to and shape this fraternal enterprise? Admittedly this is a question that poses considerable challenges for historians of the period. The closest we get are two contrasting examples: one is a photograph of a letter from a young orphan girl to 'petit père' (the name by which the children addressed Léopold Bellan) asking after his health and, rather surprisingly, using the familiar ' $t u$ ' form (Charenton, 63). The other is a brief allusion to a rare setback for the Association in 1919, when a 'horticultural orphanage' for adolescent boys was abruptly closed just months after opening on account of 'the presence of a few rowdy apprentices' ('la présence de quelques apprentis indociles') (Charenton, 72). In effect these working-class youths from the city were being introduced to agricultural labour, 
and historians scouring the archives for signs of resistance would doubtless have made more of this failure to inculcate the virtues of the soil. Charenton does not specify what happened to the boys involved, though presumably they were swiftly returned to the 'cold and impersonal' care of the state.

Born half a century after Léopold Bellan, Pierre Laroque (1907-97) is widely known as the chief architect of reforms that established France's post-war welfare state. He came from an educated bourgeois background, pursued a brilliant career in the civil service and was closely engaged in intellectual debates among 'non-conformist' reformers during the interwar years. Yet for all these differences, Eric Jabbari's study makes clear that Laroque was also an inheritor of the solidariste tradition - indeed, he was still espousing many of its precepts in his 1993 memoirs (Jabbari, 2).

The historiography has long moved away from seeing the welfare state as a post-Liberation rupture, a new social democratic year zero inspired by the zeitgeist of the Beveridge Report and the Resistance. In institutional terms, historians have pinpointed how the system that emerged after 1945 was in many ways shaped by piecemeal interwar reforms to social insurance, family allowances and healthcare. ${ }^{13}$ In the aftermath of the First World War various factors - including promises made amidst the union sacrée, growing labour unrest and the recovery of Alsace-Lorraine with its conspicuously effective German social insurance scheme - all pushed towards greater state intervention to protect against the risks of maternity, sickness, accidents and old age. It took years of wrangling and debate before the first social insurance legislation was passed in 1928, but, by the

13 See, for example, Baldwin, Social Solidarity, and Paul V. Dutton, Origins of the French Welfare State: The Struggle for Social Reform in France, 1914-47 (Cambridge: Cambridge University Press, 2002). 
late 1930s, a complex system had emerged in which an array of actors had entrenched roles. As Jabbari shows, Laroque came to master the details of these issues through successive posts at the Conseil d'Etat, in the cabinet of the Minister of Labour Adolphe Landry and later at the Conseil National Economique.

Writing in 1935, however, Pierre Laroque judged existing welfare arrangements inadequate on multiple levels: 'The allocated benefits only partially cover the insured risks, the administrative mechanism is heavy, complex, the obligatory principle is not even strictly enforced.' (Jabbari, 27.) His first opportunity to devise an alternative came shortly after France's defeat, when he was recruited to the Ministry of Labour. There Laroque contributed to proposals for a centralised staterun system of insurance that was immediately blocked by other forces within the Laval government, and he was subsequently dismissed under the anti-Semitic Vichy legislation of October 1940. He later joined the Free French in London, and at the Liberation was appointed Director of Social Security. With political momentum and ministerial support, the new project he authored provided for a universalist national system defined by the principles of rationalisation (integrating employerrun family allowance funds and mutualist-run social insurance funds), participation (via administrative councils that would be trade-union dominated) and solidarity (through a Caisse Nationale de Sécurité Sociale -National Social Security Fund- that would gradually extend to all citizens).

Laroque's post-war project was steamrollered through the first Constituent Assembly via the ordonnances of 4 and 19 October 1945 but ran into sustained opposition with the return of 'normal politics' between 1946 and 1948. Most significantly, a revolt against the redistributive implications of a central pension fund by cadres (middle-management) opened a breach into which others poured - artisans and small business owners also refused to participate, and later workers in sectors that had their own well-established insurance funds, such as railwaymen and miners, followed suit. 
As a result, a system of separate occupation-based regimes emerged which, Jabbari argues plausibly, 'reflected the social fragmentation of post-war France' (Jabbari, 153). Such compromises partially unravelled the universalist and redistributive ambitions of the scheme, and the welfare state that finally emerged owed much to what had preceded it. As Dutton has observed: 'Laroque and his successors had little choice but to build their edifice on top of these foundations. They could use new materials, build higher, and add many rooms, but the outlines of the old system would always be visible. $^{14}$

While this institutional history is necessary to comprehend Laroque's role in the creation of the welfare state, the primary objective of Jabbari's book is not to recount a fairly familiar story. Rather, the real originality resides in his analysis of Laroque's intellectual journey, providing insights into the inspiration that lay behind the technical issues at stake in his proposals. From Durkeim to Céline Bouglé and Léon Bourgeois, this solidariste tradition was complemented by Laroque's immersion in administrative law where Jabbari draws attention to the influence of Léon Deguit and Maurice Hauriou. The early chapters of the book deal deftly with these complex ideas, and tie them convincingly to the central figure of Laroque through close analysis of his personal correspondence along with the numerous reports, articles and theses he authored during the 1930s. Jabbari also explores Laroque's involvement with planiste and technocratic groups $X$-Crise and the Groupe du 9 Juillet. Rejecting Marxist critiques of capitalist society, these reformist circles sought alternative solutions to tensions between employers and a divided trade union movement, and Laroque was drawn briefly to the trompe l'œil of corporatism in fascist Italy - though the author 
argues that he remained firmly wedded to republican and democratic principles (Jabbari, 75-6). ${ }^{15}$ Comparison to his British contemporary William Beveridge is also instructive. Like Beveridge, Laroque saw the new post-war welfare state as part of a wider modernising project grounded in full employment and promoted by an activist state intervening through socio-economic policy. Unlike Beveridge, he also believed in decentralisation and participation as instruments 'to address working class alienation while transforming social relations' (Jabbari, 163). True to solidariste tradition, it was never entirely clear how such a transformation would operate. Jabbari concludes by noting the paradox of Laroque's technocratic utopianism: participation and solidarity were the cornerstones of a plan that could only be passed using the exceptional powers of the Provisional government and which met with widespread public indifference.

Eric Jabbari has produced a study of real depth, exploiting a wide range of new archival material in order to illuminate the genesis of the Plan Laroque: a plan which, notwithstanding its dilution, forms the basis of the French welfare state today. Pierre Laroque emerges as an impressive philosopher-technocrat, though one who clearly lacked the political astuteness of Jean Monnet. ${ }^{16}$ The book ends rather abruptly in 1948 on a note of mitigated defeat that seems slightly puzzling. Given that incremental reforms over subsequent decades have produced one of the most generous and comprehensive welfare states in the world, the question arises as to what was really at stake in

15 For a slightly contrasting view, see François-Xavier Merrien, Etude comparative de l'édification et de l'évolution de l'Etat protecteur en France et en Grande-Bretagne (Paris: MIRE, 1990).

16 Philip Nord places both figures onto a much broader interpretative canvas as carriers of a 'not-so-Left' modernisation project spanning the Third and Fourth Republics. See Philip Nord, France's New Deal from the Thirties to the Postwar Era (Princeton: Princeton University Press, 2010). 
Laroque's thwarted universalist ambitions. ${ }^{17}$ Here the author offers no real clues as to how we might situate this episode within that subsequent history, which leaves his conclusion hanging in something of a vacuum.

While Jabbari sees Laroque as having firmly turned against authoritarian conceptions of corporatism by 1938, the career of his ministerial boss René Belin - who remained Minister of Labour in the Laval administration until 1942 - illustrates the perils of 'third way' aspirations to transcend social conflict. From the anti-Communist wing of the CGT, Belin too had been involved in $X$-Crise during the 1930 s and represented a neo-syndicalist tendency within the ideological morass of Vichy. The plans that emerged from his ministry in 1940 envisaged labour and management representatives combining through organisational structures under the auspices of the state, an arrangement that was anathema to the more reactionary currents of the regime that sought the abolition of class divisions rather than their institutionalisation. Instead, Belin signed into law the suppression of independent trade unions (9 November 1940), as well as the Charte de Travail (4 October 1941), which, for all its corporatist language, was ultimately folded into the regime's authoritarian agenda. Jean-Pierre Le Crom analysed this fiasco in a previous work, ${ }^{18}$ and in $A u$ Secours Maréchal! L'instrumentalisation de l'humanitaire (1940-44) he turns to the field of humanitarian action under Vichy.

17 On the subsequent development of France's welfare state, see Bruno Palier, Gouverner la sécurité sociale: les réformes du système français de protection sociale depuis 1945 (Paris: Presses Universitaires de France, 2002) and Bruno Valat, Histoire de la Sécurité sociale, 1945-67: L'Etat, l'institution et la santé (Paris: Economica, 2001).

18 Jean-Pierre Le Crom, Syndicats, nous voilà: Vichy et le corporatisme (Paris: Editions de l'Atelier, 1995). 
The extraordinary disruption and psychological shock of the French defeat had made service under Marshal Pétain seem plausible to figures from radically different political horizons. It also threw up huge logistical challenges, with millions of refugees created by civilian evacuations before the German military advance and the economic and administrative dislocation caused by the country's division into occupied and unoccupied zones. In this context, calls for solidarity took on a new immediacy. Yet behind the 'apolitical' appearance of these humanitarian slogans, Le Crom reveals a host of competing ideological and institutional agendas.

Drawing on an impressive range of archival material, this study focuses on three aid organisations: the Secours national (SN), the Croix-Rouge and the Artisans du devoir patriotique (ADP). The first of these groups is at the heart of the book, a semi-public 'state within the state' that by 1942 employed a staff of several thousand, ran a budget equivalent to over 3 per cent of the total tax revenues of the French government (Le Crom, 142 and 148) and also served as an important propaganda tool for Pétain. Meanwhile, the Croix-Rouge française underwent a forced merger of its three pre-existing federal structures. Although it lost the right to make direct public appeals, its international affiliation to the Red Cross movement gave it a margin of manoeuvre - notably in gaining access to POWs in the Occupied zone. The third group Le Crom analyses, the Artisans $d u$ devoir patriotique, emerged from Colonel de La Rocque's reactionary Croix-de-Feu movement. Following the armistice the ADP tactically withdrew from overt political activity in favour of a Maréchaliste patriotic and social øuvre, but the organisation's anti-collaborationist nationalism ultimately led to the arrest and deportation of de La Rocque and other leading militants. With considerable nuance and skill, Le Crom uses these case studies to bring out a number of established themes in the historiography on Vichy. In particular, his account vividly illustrates the chaotic organisation and factionalism of the regime, its precarious but genuine autonomy via-à-vis the 
German authorities, and the ambiguity of individual trajectories that often defied a straightforward 'resistance-collaboration' paradigm.

The blurring of boundaries is a recurring feature of the story Le Crom narrates. The 'dark years' of 1940-44 eroded distinctions between public and private action, between emergency relief and quotidian social services, and between political and non-political activities. ${ }^{19}$ In principle the SN enjoyed a monopoly over public appeals for donations, and campaigns featuring postcard images of the Marshal initially met with huge success. By 1941, however, diminishing returns and the increasingly elastic category of 'civilian victims of the war' - as temporary disaster relief gave way to soup kitchens for growing swathes of the population - combined to produce significant budget shortfalls (Le Crom, 93). The slack was taken up by government subsidies and the proceeds from expropriated Jewish property. Le Crom makes clear that both the SN and Croix-Rouge benefitted directly from the latter, and, notwithstanding instances of local organisers sheltering Jewish children from deportation, the overall picture is not one of conspicuous dissent towards escalating persecution (Le Crom, 60-66, 87-9).

The scope of the study extends well beyond the main trio of national organisations to encompass local case studies throughout France. At times, particularly during early chapters on committees and structures, the detail can become repetitive and a little trying. Discussing the strained relationship between Bordeaux mayor Adrien Marquet and the regional head of the SN, Le Crom announces he will confine himself to four examples (Le Crom, 69). That said, his meticulousness is always in the service of a wider argument, and the book is above all characterised by its poised analysis. 
If Le Crom ultimately sees these years as a period of exception, he also identifies elements of continuity. One of these concerns the domain of 'action sociale' (social work or social services), where an affiliation with the values and outlook of Maréchalisme could be seen as having origins in the nineteenth century. The official Vichy slogan 'Travail, famille, patrie' was borrowed from La Rocque's Croix de Feu movement, but stripped of its overt political connotations it was also a plausible motif for the conservative and distinctly middle-class milieu of action sociale. Paternalist, pro-natalist and patriotic, many were predisposed to a moralising agenda that claimed to substitute compassion for class politics. In effect, under Vichy the 'social question' was reduced to a social slogan: 'la politique divise; le social rassemble' (politics divides; the social unites) (Le Crom, 322). If Maréchalisme drew upon a wide range of political ideas and affinities, it also served to discredit a number of them in the wake of the Liberation. ${ }^{20}$ Corporatism was one of these, as was a certain bourgeois Catholic tradition of ministering to the poor. ${ }^{21}$ Somewhat ironically given the extent of bureaucratisation and government interference between 1940 and 1944, this legacy also contributed to the post-war trend towards professionalisation and state regulation of social services.

For all their differences, these four books together help to shed light on the emergence of France's welfare state - not least the contrast, noted by Denis Pelletier, between the noble ideal and 'the frequently disheartening meanders of its realisation'. ${ }^{22}$ These works also underscore the

20 Of the major organisations Le Crom examines, all but the Croix Rouge Française had been dissolved by 1949.

21 As Le Crom observes, referring to Jeannine Verdès-Leroux’s Le Travail social (Paris: Editions de Minuit, 1978), this retrospective opprobrium has sometimes lacked nuance (p. 130).

22 Denis Pelletier, reviewing Bruno Valat's Histoire de la sécurité sociale in Histoire, économie et société, 22 (2003), my translation. 
enduring importance of 'solidarity' as a concept in French political life, hovering awkwardly between fraternity and equality and tempered by liberty. During the first half of the twentieth century it formed a central tenet of various strands of 'third way' political thought that sought to overcome entrenched divisions of class and ideology: solidarisme, néo-socialisme, even Maréchalisme. At the same time, these political visions of social transformation were closely intertwined with practical expressions of solidarity, whether in the domain of philanthropy, social insurance or humanitarian assistance.

Thinking about these connections brings to mind the French intellectual Pierre Rosanvallon. ${ }^{23}$ A distinguished theorist of democracy and of the history of political thought, his ideas and engagements carry unmistakeable echoes of the solidariste tradition, with his rejection of ideological polarisation and early interest in the concept of 'civil society' as a pillar of democratic pluralism. His passage through the mutualist Confédération Française des Travailleurs Chrétiens and the 'deuxième gauche' in the 1970s, and his later involvement with the Saint-Simonian moment of the late 1980s as co-author of La République du centre. La fin de l'exception française (1988) further attest to a particular cast of 'third way' thinking. A second, more direct, link between Rosanvallon and these books is his interest in the welfare state. ${ }^{24}$ One of the arguments he has advanced is that the increasing personalisation of risk assessment is rendering the social insurance model of solidarity untenable - put simply, the more we know about our individual exposure to illhealth, accidents or unemployment, the less willing we will be to pool these risks with those more

23 For an English translation of some of his key texts, see Pierre Rosanvallon, Democracy Past and Future: Selected Essays (New York: Columbia University Press, 2006).

24 See Pierre Rosanvallon, La Nouvelle Question sociale: repenser l'Etat-providence (Paris: Seuil, 1995). 
exposed than ourselves. This erosion of solidarity he sees as ineluctable within the framework of the contemporary welfare state, and therefore dismisses those seeking to rehabilitate a post-1945 socialdemocratic ethos as engaging in the politics of nostalgia. ${ }^{25}$

Two points would seem to follow from this. One is that the type of solidarity that has characterised post-war welfare states like the French one relies as much on calculations of selfinterest as on any loftier egalitarian ideal. The second point concerns an important distinction between progressives past and present, between the architects and the caretakers of welfare state regimes. For both Beveridge and Laroque, the institutions of the welfare state were part of wider projects of societal transformation rather than simply ends in themselves. The contrast with today serves to highlight the essentially defensive nature of contemporary social democratic politics, as the centre-left seeks to trim its sails to the winds of 'reform'. It seems particularly ironic, then, that two of the features which Pierre Laroque hoped to eradicate from France's welfare system institutional complexity and fragmentation by occupation group - are now the most formidable barriers to its erosion by the neo-liberal tide. ${ }^{26}$

25 Pierre Rosanvallon, 'From Equality of Opportunity to the Society of Equals', paper presented at the Maison Française d'Oxford, April 2014.

26 Susan Milner highlights the gap between 'the French ideal of solidarity and the reality of an insider-outsider labour market', while also noting, with Kaufmann, the importance of veto-players in a sectorally divided system. Milner, ‘Social policy’, 57. 